\title{
On line pre-concentration for simultaneous determination of low molecular weight organic acids and inorganic anions in Amazonian river water samples employing ion chromatography with conductivity detection
}

\author{
Cristiane Azevedo TUMANG ${ }^{1}$, Alex Vladimir KRUSCHE², Reynaldo Luis VICTORIA², \\ Jeffrey Edward RICHEY ${ }^{4}$
}

\begin{abstract}
An ion chromatography procedure, employing an IonPac AC15 concentrator column was used to investigate on line preconcentration for the simultaneous determination of inorganic anions and organic acids in river water. Twelve organic acids and nine inorganic anions were separated without any interference from other compounds and carry-over problems between samples. The injection loop was replaced by a Dionex AC15 concentrator column. The proposed procedure employed an auto-sampler that injected $1.5 \mathrm{ml}$ of sample into a $\mathrm{KOH}$ mobile phase, generated by an Eluent Generator, at $1.5 \mathrm{~mL} \mathrm{~min}^{-1}$, which carried the sample to the chromatographic columns (one guard column, model AG-15, and one analytical column, model AS15, with $250 \times 4 \mathrm{~mm}$ i.d.). The gradient elution concentrations consisted of a $10.0 \mathrm{mmol} \mathrm{l}^{-1} \mathrm{KOH}$ solution from 0 to $6.5 \mathrm{~min}$, gradually increased to $45.0 \mathrm{mmol} \mathrm{l}^{-1} \mathrm{KOH}$ at $21 \mathrm{~min}$., and immediatelly returned and maintained at the initial concentrations until $24 \mathrm{~min}$. of total run. The compounds were eluted and transported to an electro-conductivity detection cell that was attached to an electrochemical detector. The advantage of using concentrator column was the capability of performing routine simultaneous determinations for ions from 0.01 to $1.0 \mathrm{mg} \mathrm{l}^{-1}$ organic acids (acetate, propionic acid, formic acid, butyric acid, glycolic acid, pyruvate, tartaric acid, phthalic acid, methanesulfonic acid, valeric acid, maleic acid, oxalic acid, chlorate and citric acid) and 0.01 to $5.0 \mathrm{mg} \mathrm{l}^{-1}$ inorganic anions (fluoride, chloride, nitrite, nitrate, bromide, sulfate and phosphate), without extensive sample pretreatment and with an analysis time of only 24 minutes.
\end{abstract}

KEY WORDS: On-line pre-concentration, inorganic anions, organic anions, ion chromatography, river waters

\section{Pré-concentração em linha para a determinação simultânea de ácidos carboxílicos de baixo peso molecular e ânions inorgânicos em amostras de rios da Amazônia empregando cromatografia de íons com detecção por condutividade elétrica}

\section{RESUMO}

A metodologia analítica foi desenvolvida empregando coluna pré-concentradora AC15 em linha na cromatografia iônica na determinação simultânea de ânions orgânicos e inorgânicos, com uso de coluna de guarda AG15 e analítica AS15, 250 x 4 mm i.d. (Dionex Corp.). O gradiente de concentração do eluente foi fixo em 10,0 mmol.1 ${ }^{-1} \mathrm{KOH}$ nos tempos de retenção de 0 até 6,5 min, seguido do aumento da concentração até 45,0 mmol.1 $1^{-1} \mathrm{KOH}$ a $21 \mathrm{~min}$, imediatamente retornando e mantendo a concentração inicial até o tempo total de análise de $24 \mathrm{~min}$. Os compostos foram separados com boa resolução e deslocados para uma cela de detecção de condutividade elétrica acoplada a um detector eletroquímico. O emprego da coluna pré-concentradora em linha apresentou vantagens analíticas na determinação de rotina dos íons na faixa linear de 0,01 até $1,0 \mathrm{mg} \mathrm{l}{ }^{-1}(\mathrm{r}=0,9989)$ de ácidos orgânicos (acético, propiônico, fórmico, butírico, glicólico, pirúvico, tartárico, ftálico, metanossulfônico, valérico, maleico, oxálico e cítrico) e 0,01 até 5,0 mg.l ${ }^{-1}(\mathrm{r}=0,9987)$ de ânions inorgânicos (fluoreto, cloreto, nitrito, brometo, nitrato, sulfato, clorato e fosfato) sem pré-tratamento da amostra. Um tempo de análise de 24 min e limite de detecção de $5 \mu . .^{-1}$ foram obtidos para os ânions orgânicos ácido ácetico, ácido fórmico, ácido butírico, ácido glicólico, ácido valérico, ácido cítrico e de $10 \mu \mathrm{g} . \mathrm{l}^{-1}$ para ácido propiônico, piruvato, ácido tartárico, ácido ftálico, ácido metasulfônico e ácido maleico. Para os ânions inorgânicos $2 \mu \mathrm{g} . \mathrm{l}^{-1}$ de fluoreto, cloreto, nitrato, brometo, sulfato e $10 \mu \mathrm{g} . \mathrm{l}^{-1}$ de clorato, nitrito e fosfato foram estimados, segundo metodologia sugerida por IUPAC.

PALAVRAS-CHAVE: Pré-concentração em linha, ânions inorgânicos, ânions orgânicos, cromatografia de ions, rio Amazonas.

\footnotetext{
1 Universidade Federal de Uberlândia - UFU. e-mail: cristiane@iqufu.ufu.br

2 CENA/USP. e-mail: alex@cena.usp.br

3 CENA/USP. e-mail: reyna@cena.usp.br

${ }^{4}$ University of Washington. e-mail: jrichey@u.washington.edu
} 


\section{INTRODUCTION}

In aquatic environments bacteria are primarily responsible for the biochemical decomposition of organic matter. The efficiency in which bacteria use dissolved organic carbon is an important factor governing the flow of carbon and energy through the microbial food chain. In this process complex materials can be converted to low-molecular-weight compounds (Vallino et al., 1996). Recent studies have demonstrated that some low molecular weight compounds also result from photooxidation of humic substances as well as excretion by algae and cyanbacteria during carbon assimilation (Karlsson, 1999). In fact, although these labile organic acids are present at low concentrations, (at the $\mu \mathrm{g} . \mathrm{l}^{-1}$ level), as a group they may account for approximately 5 to 8 $\%$ of the dissolved organic carbon (DOC) of natural waters (Thurman, 1985).

Experimental studies have been conducted to characterize the composition of dissolved organic matter, examine its production and utilization, understand its impact on microbial dynamics and determine the extent to which it supports higher tropic levels (Vallino et al., 1996), several of those in aquatic environments (Findlay \& Sinsabaugh, 2003). Low molecular weight organic acids (LMWOA) have been also identified and measured in a wide variety of environments, such as soil solution, atmosphere, rivers, snow, and sea waters (Thurman, 1985; Souza et al., 1999; Albert \& Martens, 1997; Strobel, 2001) and analyzed in other matrices (Toofan et al., 1997; Ding et al., 1997; Eiteman \& Chastain, 1997; Morales et al., 1998; Klampfl et al., 2000; Sharma et al., 1998).

Initially, analyses of low molecular weight carboxylic acids were determined by paper chromatography. For the last two decades, routine analysis often employ chromatographic techniques such as gas chromatography (Kuiters $\&$ Denneman, 1987), high performance liquid chromatography and suppressed and non-suppressed ion chromatography (Dahlén et al., 2000; Strobel, 2001). More recently, capillary zone electrophoresis has also been used for these determinations (Dahlén et al., 2000; Findlay, 2003).

The short chain carboxylic acids which can partly be dissociated to anionic forms in aqueous solution can also be separated by suppressed ion chromatography (IC) with conductivity detection. However, most published methods appear to be unsuitable for application to environmental samples with organic acid concentrations in the presence of inorganic anions because high concentration of inorganic anions interfere in the separation of low concentration of organic acids (Ding et al., 1997; Fang, 1993). Nevertheless, sampling and sample preparation are often critical in the determination of trace constituents in natural waters due to, for example, hydrolysis, volatilization and biodegradation (Ding et al., 1997). In the case of LMWOA, there is still a scarcity of procedures concerning the simultaneous determination of the organic and inorganic anions in river waters.

Ion chromatography allows adding the concentrator columns in replacement of sample loops, using a six port switching valve. The advantage of this option is the ability to perform routine analysis for ions at $\mu \mathrm{g} . \mathrm{l}^{-1}$ levels without prior off-line sample treatment, increasing the throughput of determinations per hour. On another hand, there are several difficulties that must be investigated in order to evaluate the parameters that could affect the behavior of inorganic anions and organic acids during on-line pre-concentration (Fang, 1993).

In this work we present an analytical methodology for the simultaneous on-line pre-concentration, separation and determination of organic acids and inorganic anions in river waters using ion chromatography. Several parameters were tested, such as relationship between sample loading and injection flow-rate, sample volume, interferences, suppressor current setting and concentration of the elution gradient. After optimization, several river water samples were analyzed.

\section{MATHERIAL AND METHODS}

\section{INSTRUMENTATION}

The ion chromatograph used in this work consisted of a Dionex Corporation DX-500 system equipped with an AS50 Auto select Autosampler containing a 9126 Rheodyne 6-port injection valve, a GP50 gradient pump, an EG40 eluent generator system with EluGen ${ }^{\mathrm{TM}} \mathrm{EGC}-\mathrm{KOH}$ cartridge, an ASRS ULTRA II $4 \mathrm{~mm}$ self-regenerating suppressor and an ED40 conductivity detector. Dionex IonPac AS15 (250 x 4 mm i.d.), AG15 ( $250 \times 4 \mathrm{~mm}$ i.d.) and AC15 (4 x $50 \mathrm{~mm}$ i.d.) were used, respectively, as guard, analytical and concentrator columns. The PeakNet 6.0 software was used for system control and data collection.

\section{REAGENTS AND PROCEDURES}

All carboxylic acid standards were prepared from analytical reagent grade chemicals (>99\% pure) in $18.3 \mathrm{M} \Omega$ water, obtained from a Barnstead Nanopure Infinity water purification system. Individual stock solutions of 1000 mg..$^{-1}$ fluoride, chloride, nitrite, nitrate, bromide, sulfate, phosphate, acetate, propionic acid, formic acid, pyruvate, maleic acid, oxalic acid, chlorate and citric acid were prepared from their analytical reagent grade sodium salts (except for methanesulfonic acid, $\mathrm{n}$-valeric acid, butyric acid, phthalic acid, glycolic acid, L-tartaric acid, oxalic acid, which were prepared from liquid standards). Each $250 \mathrm{ml}$ of the standard solutions received $25.0 \mathrm{mg}$ of thymol to protect carboxylic acids from bacterial decomposition, and were stored in amber glass bottles at $4^{\circ} \mathrm{C}$. Working calibration standard solutions 
$0.0 ; 0.01 ; 0.025 ; 0.05 ; 0.1 ; 0.25 ; 0.5 ; 1.0 ; 2.5$ and $5.0 \mathrm{mg}^{-1}$ inorganic anions and organic acids were prepared daily by appropriate dilutions of the stock solution with water.

The mobile phase was produced by an EG40 Eluent Generator System with ElunGen ${ }^{\mathrm{TM}}$ EGC-KOH cartridge commercially available from Dionex Company.

Sample solutions were taken in separate polyethylene bottles and filtered through $0.45 \mu \mathrm{m}$ membrane filter, spiked with thymol and kept refrigerated in amber polyethylene bottles at $4^{\circ} \mathrm{C}$. This sample solution was injected into the ion chromatograph directly.

A Rheodyne 9126 valve with a rotor that converts the valve from 6 ports with a needle port to a 6 port valve can be used to configure a concentrator column in a sample injection system. The sample is introduced through port 6 rather than the needle port. In the load position, sample enters the valve at port 6 , flows out of the valve at port 1 to the concentrator column, back into the valve through port 4 , and out to waste through port 5 . The eluent enters the valve at port 3 and flows to the analytical column through port 2 (Figure 1 ). In the inject position, the eluent is pumped into the valve at port 3 and out of the valve at port 4 to the concentrator column to elute the analytes to the analytical column. With this configuration, the analytes are concentrated in one direction on the concentrator column and eluted to the analytical column in the opposite direction. In general, reversed flow elution decreases the dispersion of the concentrate during elution and improves the enrichment factors (Toofan et al., 1997).

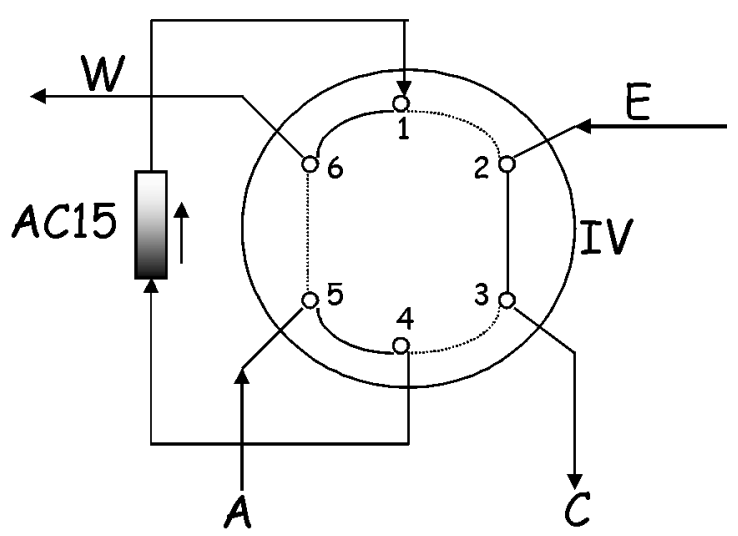

Figure 1 - Process for loading the lon Pac AC15 concentrator column. IVinjection valve; C- to guard and analytical column; E- eluent in; W- waste; AC15- concentrator column; A- sample in. Solid and dashed lines indicate the flow pathways in the valve.
The effects of parameters, such as sample loading and injection flow rates, sample volume, interferences, suppressor current settings and gradient elution comprised the set of variables that were investigated to establish the best operational conditions. All samples were also preserved with thymol and kept frozen until analysis (Chen et al., 1999). Before manipulation samples were equilibrated to the laboratory temperature. All sample measurements were performed in triplicates and the average peak area was used in these studies.

\section{RESULTS AND DISCUSSION}

\section{CHOICE OF THE ANALYTICAL COLUMN AND EFFECTS OF SAMPLE VOLUME}

The IonPac AS11-HC and AS15 analytical columns in combination with the AG11 and AG15 guard column, respectively, are designed for the trace analysis of inorganic anions and low molecular weight organic acids in complex matrices using potassium hydroxide gradient elution. The first study consisted of testing the effects of the sample volume in the available columns AS11-HC and AS15 (250 x $4 \mathrm{~mm}$ i.d.) in order to monitor the organic acid and inorganic anion responses without any previous optimizations in the method. In general, the companies suggest that low sample volume should be inserted into AS11-HC column because of the overloading effect, while the AS15 column did not have this restriction. In this sense, different sample volumes were inserted varying from 200 to $500 \mu$ with $5 \mu$ l cut volume into AS11-HC and full injection type varied from 500 to $2000 \mu \mathrm{l}$ into AS 15 column. Volumes above $2000 \mu$ were not available because sample could contaminate the flush bottle through the transfer line, which had a volume of $2200 \mu$ volume. Peak area results were observed using a reference solution containing 1.0 mg..$^{-1}$ organic and inorganic anions. This parameter control was performed to attain a better combination of selectivity and sensitivity. The result of these studies shows (Figure 2) that the area signals for all analytes increase up to c.a. $80 \%$ when the aliquot volume was increased from $200 \mu \mathrm{l}$ to $300 \mu \mathrm{l}$ with $5 \mu$ cut volume with AS11-HC column. However, this area signal increase was not observed when aliquot volumes above $300 \mu \mathrm{l}$ were inserted because this column showed overloading problems for large injections volume. Nevertheless with this column, we did not detect any of the organic anions such as pyruvate, glycolate, propionate, tartrate and maleate. Although good results with the AS11-HC were obtained, only some organic and inorganic anions could be determined in the linear range from 0.05 to $5.0 \mathrm{mg} . \mathrm{l}^{-1} \mathrm{such}$ as fluoride, acetate, formate, butirate, MSA, valerate, proprionate, nitrite, nitrate, chloride, bromide, sulfate and phosphate.

On another hand, when AS15 column was employed better results were obtained in selectivity and sensitivity for 


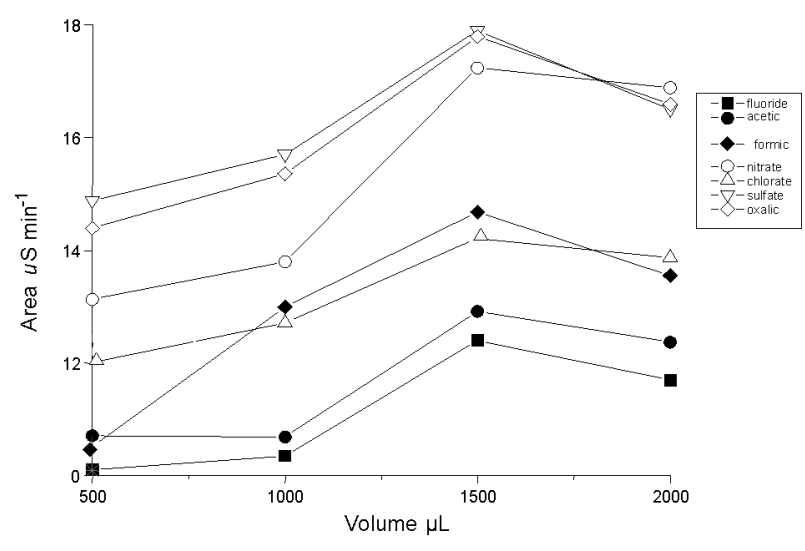

Figure 2 - Effect of the sample volume. A $1.0 \mathrm{mg} \mathrm{l}^{-1}$ organic and inorganic anions solution (fluoride, acetic acid, formic acid, nitrate, chlorate, sulfate and oxalic acid) was used maintaining the AS15 analytical column, $100 \mathrm{~mA}$ current output level and $3.0^{\circ} \mathrm{C}$ temperature.

all organic and inorganic anions in linear range from 0.05 to $5.0 \mathrm{mg} \cdot \mathrm{l}^{-1}$. With this column, a relationship between sample volume and $33 \%$ signal area increase for all organic and inorganic anions was observed when sample volume was increased from 500 to $1500 \mu \mathrm{l}$ into analytical column. Between 1500 and $2000 \mu \mathrm{l}$ of aliquot sample, no significant differences were observed in the signal. Volumes above 2000 $\mu \mathrm{l}$ were not available because samples could contaminate the flush bottle through the transfer line. These results show that the volume of sample could be used to increase sensitivity for this typical low linear concentration range. Thus, the AS15 analytical column and $1500 \mu \mathrm{L}$ were selected for further experiments.

\section{EFFECTS OF PRE-CONCENTRATION VOLUMES AND FLOW RATES}

The relationship between sample volumes and flow rates are very important factors that affect the pre-concentration step. In this sense, we investigated the best condition for the relationship between sample volume and flow rate into the AC15 concentrator column during the pre-concentration step. First, in order to investigate the effect of sample volume, different volumes of a solution containing $1.0 \mathrm{mg} . \mathrm{l}^{-1}$ of all analytes were pre-concentrated with the $\mathrm{AC} 15$ concentrator column. Volumes of 500 to $2000 \mu \mathrm{l}$ organic and inorganic anions were pre-concentrated using a fixed sample loading flow-rate of $1.8 \mathrm{ml} \cdot \mathrm{min}^{-1}$. Similar to the results obtained in the tests for choosing the type of analytical column, in this case increasing the injection volumes from 500 to $1500 \mu \mathrm{l}$ resulted in higher peak areas for both organic and inorganic anions. When $2000 \mu \mathrm{l}$ was inserted no significant differences in peak areas were observed. Peak areas were similar to those obtained when $1500 \mu \mathrm{l}$ was pre-concentrated with the AC15 concentrator column.
After establishing the $1500 \mu \mathrm{l}$ sample volume on the $\mathrm{AC} 15$ concentrator as the best alternative, we investigated the influence of flow-rate on the pre-concentration process. In this case, we tested the pre-concentration of $0.025 \mathrm{mg} . \mathrm{l}^{-1}$ organic and inorganic anions at flow rates of $1.5 ; 1.8 ; 2.0$ and 2.5 $\mathrm{ml} . \mathrm{min}^{-1}$ maintaining a current of $100 \mathrm{~mA}$ at the suppressor, $30{ }^{\circ} \mathrm{C}$ temperature at the conductivity cell and a gradient elution. The gradient started at a $\mathrm{KOH}$ concentration of 10.0 mmol. $\mathrm{I}^{-1} \mathrm{KOH}$, with retention time of 0 to $6 \mathrm{~min}$, gradually increasing to $45.0 \mathrm{mmol}^{-1} \mathrm{I}^{-1} \mathrm{KOH}$ from retention times of 6 to $14 \mathrm{~min}$ and finalizing with $10 \mathrm{mmol}^{-1} \mathrm{I}^{-1} \mathrm{KOH}$ between 20 and $29 \mathrm{~min}$ of retention time. The chromatograms showed that when flow rate is increased from 1.8 to $2.5 \mathrm{ml} \cdot \mathrm{min}^{-1} \mathrm{a}$ decrease in sensitivity was observed. Low resolution occurred between near residence time peaks of, for example, glycolate and acetate. The speed of elution was a crucial factor for the efficiency of on-line pre-concentration, with the best results attained at a flow rate of $1.5 \mathrm{ml} . \mathrm{min}^{-1}$, which was employed in further experiments. This rate was also used in the reversed flow elution which decreased the dispersion of the concentrate during elution and improved the enrichment factors (Toofan et al., 1997).

\section{GRADIENT ELUTION AND SUPPRESSION SETTINGS}

Traditionally, acid or base eluents are prepared off line by dilution from reagent grade chemicals. This process can be tedious, prone to operator errors, and often introduces contaminants. The use of EG40 eluent generator modules in ion chromatography offers significant advantages over traditional procedures. Separations can be performed using only deionized water as the carrier while the EG40 module is placed between the outlet of the pump and the inlet of the sample injector. The eluent preparation step is eliminated, since the high purity base or acid eluent is generated on line at the point of use. Another advantage of eluent generators is the convenience of eluent generator control. Gradient separations can be performed using electrical current to generate gradients with minimal delay, instead of mixing eluents with different concentrations using gradient pumps. For trace level anion determinations, an anion trap column (ATC-1) was placed at the pump outlet to remove dissolved carbon dioxide and other anionic contaminants from the deionized water.

Finally, to complete the system parameter optimization the best combination of speed and selectivity was tested using three different gradient programs. In the first program, the elution concentration gradient started at a $\mathrm{KOH}$ concentration of $10.0 \mathrm{mmol}^{-l^{-1}}$ from 0 to $3 \mathrm{~min}$, followed by a gradual increase to $45.0 \mathrm{mmol.} \mathrm{l}^{-1} \mathrm{KOH}$ from 3 to $20 \mathrm{~min}$ and finished with 10 mmol. $\mathrm{l}^{-1} \mathrm{KOH}$ from 20 to $24 \mathrm{~min}$ of retention time. The second elution program, started with the same concentration $\mathrm{KOH}$, but kept until $6.5 \mathrm{~min}$, followed by a gradual increase to $45.0 \mathrm{mmol} . \mathrm{l}^{-1} \mathrm{KOH}$ at $21 \mathrm{~min}$ and returned to $10 \mathrm{mmol}^{-\mathrm{l}^{-1}}$ 
$\mathrm{KOH}$ between 21 and $24 \mathrm{~min}$ of retention time. For the last gradient elution program, $\mathrm{KOH}$ concentrations also started at $10.0 \mathrm{mmol}^{-\mathrm{l}^{-1}}$ until $3 \mathrm{~min}$., increased gradually to $45 \mathrm{mmol} . \mathrm{l}^{-1}$ at $14 \mathrm{~min}$, and then were decreased to $10.0 \mathrm{mmol.l^{-1 }}$ from 14 to 24 min of retention time.

The first and third gradient elution programs showed low separation efficiency for organic anions with short retention times (from 0.0 to $3.0 \mathrm{~min}$ ) employing $10 \mathrm{mmol}^{-1} \mathrm{I}^{-1} \mathrm{KOH}$ eluent concentration, such as acetic and glycolic acids, formic and propionic acids. Therefore, adjustments were necessary to attain the proper eluent concentrations at the correspondent residence times. Problems with co-elution were minimized when the second gradient elution was used, keeping initial low concentration eluent from 0.0 to 6.5 min retention time. This interval of time has an eluent weak enough to retain, for example, fluoride well out of the void volume and separates several weakly retained monoprotic organic acids from inorganic anions. Also, the adjusts made on the final eluent concentration with retention time was capable of eluting triprotic phosphate and citrate. Thus, adjustment of the retention time allows better selectivity among analytes. The optimum conditions for a gradient elution were obtained with

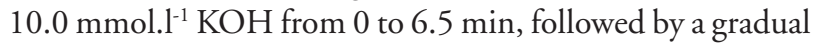
increase to $45.0 \mathrm{mmol}^{-1} \mathrm{I}^{-1} \mathrm{KOH}$ from 6.5 to $21 \mathrm{~min}$ and a 10 mmol. $1^{-1} \mathrm{KOH}$ between 21 and 24 min of retention time. analysis. When high concentration elution was used, such as

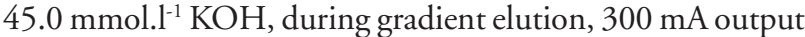
levels were better, because lower background conductivity could be achieved. Therefore, for the remaining experiments we used a gradient elution program started and kept at 10.0 mmol..$^{-1}$ for 6 min., then gradually increased to achieve 45.0 mmol..$^{-1} \mathrm{KOH}$ at $21 \mathrm{~min}$. and immediately returned to 10 mmol..$^{-1} \mathrm{KOH}$ until $24 \mathrm{~min}$. of retention time, with a fixed current of $300 \mathrm{~mA}$ at the suppressor column.

\section{SAMPLE ANALYSIS}

Once the experimental variables were optimized, a set of river water samples were processed in order to verify the feasibility of the proposed system, yielding the results of Tables 1 and 2. Although several compounds were identified in these waters, proving the method suitable for the simultaneous analysis of both organic and inorganic compounds, according to Souza (1998), certain species interact similarly with exchange resin sites and may not always be detected, misleading the interpretation of environmental data sets. Typical examples include co-elution of acetate/lactate peaks. To test if that was the case with the method proposed here, we added to the samples standard solutions containing 0.25 and $0.50 \mathrm{mg} . .^{-1}$ lactate, both with $0.25 \mathrm{mg} . \mathrm{l}^{-1}$ acetate. Peak area results showed no significant interference during co-elution of acetate and lactate. Added lactate concentration was two-fold of that usually found in river water. Nevertheless, in natural

Table 1 - Determination of organic anions in Amazonian rivers samples.

\begin{tabular}{|c|c|c|c|c|}
\hline Anions Organic & & & & \\
\hline$\left(\mathrm{mg} \mathrm{l}^{-1}\right)$ & Ji-Paraná & Comemoração & Igarapé Boa Vista & Urupá \\
\hline acetic acid & $0.282 \pm 0.002$ & $\mathrm{nq}$ & $\mathrm{nq}$ & $0.254 \pm 0.002$ \\
\hline Glycolic acid & $0.054 \pm 0.002$ & $\mathrm{nq}$ & $\mathrm{nq}$ & $\mathrm{nq}$ \\
\hline propionic acid & $\mathrm{nq}$ & $\mathrm{nq}$ & $0.013 \pm 0.001$ & $0.013 \pm 0.001$ \\
\hline formic acid & $0.761 \pm 0.002$ & $0.631 \pm 0.002$ & $\mathrm{nq}$ & $\mathrm{nq}$ \\
\hline butyric acid & $0.090 \pm 0.002$ & $0.235 \pm 0.002$ & $0.159 \pm 0.002$ & $0.355 \pm 0.002$ \\
\hline pyruvate & $\mathrm{nq}$ & $\mathrm{nq}$ & $0.037 \pm 0.002$ & $0.075 \pm 0.002$ \\
\hline tartaric acid & $\mathrm{nq}$ & $0.327 \pm 0.002$ & $0.263 \pm 0.002$ & $\mathrm{nq}$ \\
\hline phtalic acid & $\mathrm{nq}$ & $\mathrm{nq}$ & $\mathrm{nq}$ & $\mathrm{nq}$ \\
\hline methanesulfonic acid & $\mathrm{nq}$ & $\mathrm{nq}$ & $\mathrm{nq}$ & $\mathrm{nq}$ \\
\hline valeric acid & $0.368 \pm 0.002$ & $0.261 \pm 0.002$ & $0.259 \pm 0.002$ & $\mathrm{nq}$ \\
\hline maleic acid & $\mathrm{nq}$ & $\mathrm{nq}$ & $0.169 \pm 0.002$ & $\mathrm{nq}$ \\
\hline citric acid & $0.193 \pm 0.002$ & $0.331 \pm 0.002$ & $0.591 \pm 0.002$ & $0.392 \pm 0.002$ \\
\hline
\end{tabular}

Results expressed as means \pm S.D. from triplicate measurements. $\mathrm{nq}=$ no quantitated

The chemical suppression technology allows the increase in analyte conductivity and the decrease in the background eluent conductivity, resulting in an improvement in analyte detection limits. Different current output levels such as 50; 100 and $300 \mathrm{~mA}$ could be used in this module. Choosing the right current depends on the elution concentration during the water samples, acetate determination is considered to be more important than lactate (Dahlén et al., 2000).

The set of samples from Amazonian rivers was analyzed by ion chromatography and results are presented in Tables 1 and 2. Figure 3 shows the chromatograms typical obtained with blank solution and sample solution, demonstrating that no 
Table 2 - Determination of inorganic anions in Amazonian rivers samples.

\begin{tabular}{lccccc}
\hline Anions Inorganic & \multicolumn{2}{c}{ River samples } & & \\
\cline { 1 - 2 }$\left(\mathrm{mg} \mathrm{l}^{-1}\right)$ & Ji-Paraná & Comemoração & & Igarapé Boa Vista & Urupá \\
\hline fluoride & $0.066 \pm 0.001$ & $0.081 \pm 0.001$ & & $0.089 \pm 0.001$ & $0.014 \pm 0.001$ \\
chloride & $0.341 \pm 0.001$ & $0.553 \pm 0.001$ & & $1.616 \pm 0.001$ & $1.378 \pm 0.001$ \\
nitrite & $\mathrm{nq}$ & $\mathrm{nq}$ & $\mathrm{nq}$ & $\mathrm{nq}$ & $0.055 \pm 0.001$ \\
nitrate & $0.478 \pm 0.001$ & $0.123 \pm 0.001$ & & $0.111 \pm 0.001$ & $0.774 \pm 0.001$ \\
bromide & $0.141 \pm 0.001$ & $0.132 \pm 0.001$ & & $1.043 \pm 0.001$ & $0.068 \pm 0.001$ \\
sulfate & $0.089 \pm 0.001$ & $0.065 \pm 0.001$ & & $0.087 \pm 0.001$ & $0.285 \pm 0.001$ \\
phosphate & $0.153 \pm 0.001$ & $0.215 \pm 0.001$ & & $0.515 \pm 0.001$ & $0.024 \pm 0.001$ \\
\hline chlorate & $\mathrm{nq}$ & $0.022 \pm 0.001$ & & $0.018 \pm 0.001$ & \\
\hline
\end{tabular}

Results expressed as means \pm S.D. from triplicate measurements.

$\mathrm{nq}=$ no quantitated

problems with carry-over occurred. Accuracy was ascertained by standard addition techniques of the $0.00 ; 0.05 ; 0.01$ and $0.025 \mathrm{mg}^{-1} \mathrm{l}^{-1}$ organic and inorganic anions and achievement of recoveries ranging from 97 to $107 \%$. By applying the student $t$-test to the average recoveries, no significant difference at the 95\% confidence level was observed.

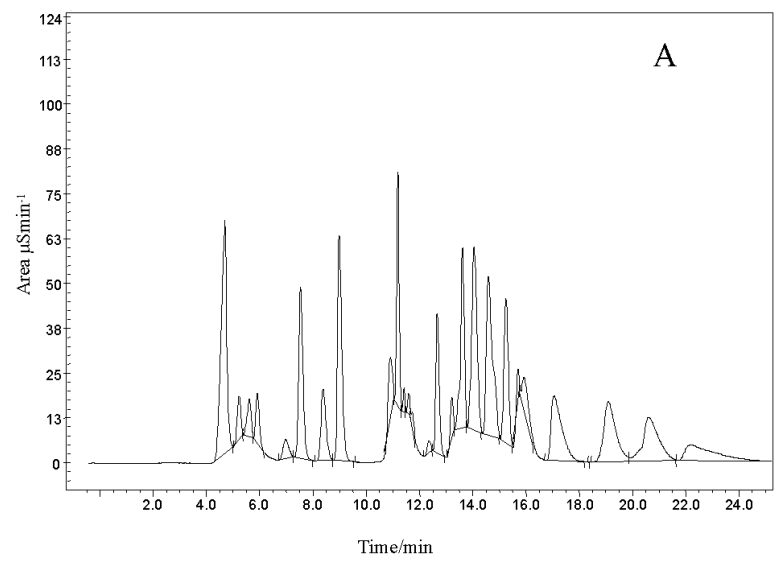

response range from 0.01 to $1.0 \mathrm{mg}^{-1} \mathrm{l}^{-1}$ for organic anions (acetic acid, propionic acid, formic acid, butyric acid, glycolic acid, pyruvate, tartaric acid, phthalic acid, methanesulfonic acid, valeric acid, maleic acid, oxalic acid, chlorate and citric acid) and 0.01 to $5.0 \mathrm{mg} . \mathrm{l}^{-1}$ for inorganic anions (fluoride, chloride, nitrite, nitrate, bromide, sulfate and phosphate); glycolic acid ( $r=0.997)$, acetic acid $(r=0.997)$, formic acid $(r=0.997)$, propionic acid $(r=0.997)$, methanesulfonic acid

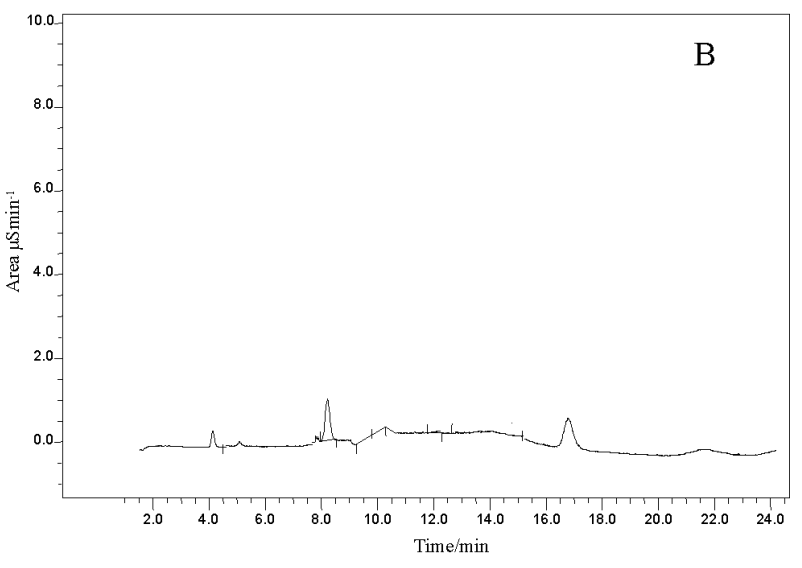

Figure 3 - Chromatograms typical obtained of the run system with preconcentration process. A- Sample solution; B- Blank solution.

Figure 4 shows the chromatograms typically obtained with $1.5 \mathrm{ml}$ sample volume without and with pre-concentration steps of a standard solution containing $0.025 \mathrm{mg} .1^{-1}$ organic and inorganic anions. This figure also illustrates the advantages in sensitivity achieved with the use of the concentrator in LMWOA determination.

The proposed method includes several other favorable features, such as relative standard deviation of $2.0 \%(n=5)$ for a typical sample presenting $0.5 \mathrm{mg} .1^{-1}$ of all analytes; a linear $(\mathrm{r}=0.999)$, butyric acid ( $\mathrm{r}=0.997)$, tartaric acid ( $\mathrm{r}=0.999)$, maleic acid $(r=0.997)$, oxalic acid $(r=0.997)$, phthalic acid $(\mathrm{r}=0.996)$, citric acid $(\mathrm{r}=0.996)$, fluoride $(\mathrm{r}=0.997)$, chloride $(r=0.999)$, nitrite $(r=0.999)$, chlorate $(r=0.999)$, nitrate $(r=0.998)$, sulfate $(r=0.998)$, bromide $(r=0.997)$ e phosphate $(\mathrm{r}=0.996)$. Also an analysis time of only 24 minutes and limit of detection of $5 \mu \mathrm{g} . \mathrm{l}^{-1}$ for acetic acid, formic acid, butyric acid, glycolic acid, valeric acid, oxalic acid, citric acid and 10 $\mu g . l^{-1}$ for propionic acid, pyruvate, tartaric acid, phthalic acid, 

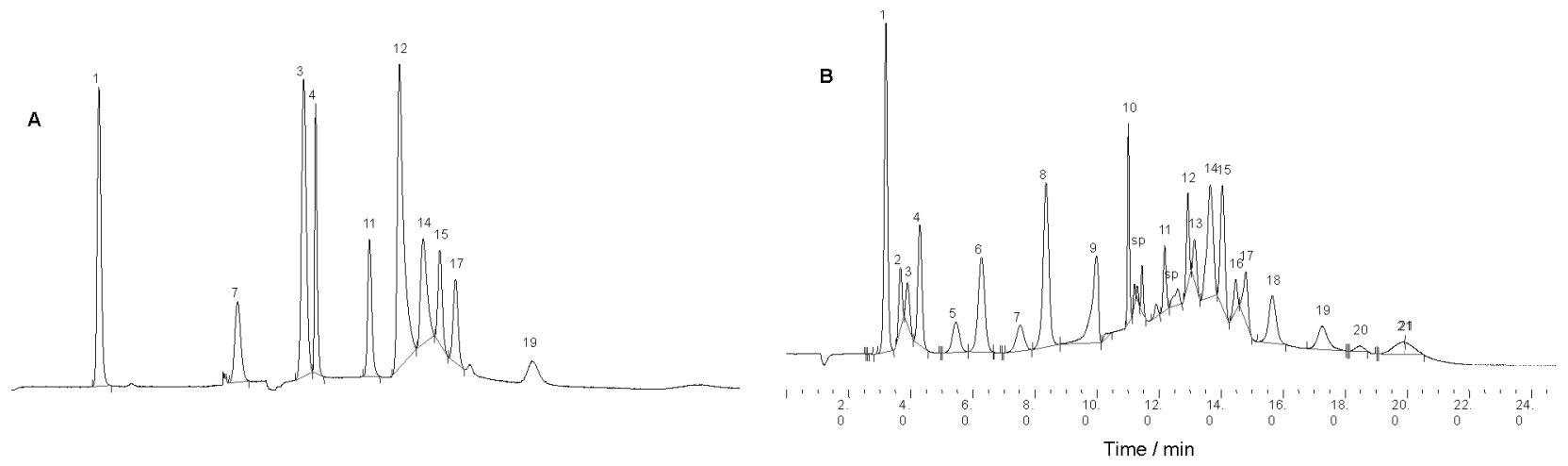

Figure 4 - Chromatograms of standard solution $0.025 \mathrm{mg} \mathrm{l}^{-1}$ organic and inorganic anions. A- without preconcentration process; B- with preconcentration process. Conditions: AC5 concentrator column; AS15 and AG15 analytical and guard column; temperature $30^{\circ} \mathrm{C}$; flow rate $1.5 \mathrm{ml} \mathrm{min}^{-1}$; conductance detector; $300 \mathrm{~mA}$ current output level and gradient elution. Peaks: $\mathrm{sp}=$ system peak; $1=$ fluoride; $2=$ glycolate; $3=$ acetate; $4=$ formate; $5=$ propionate; $6=\mathrm{MSA} ;$ 7 = pyruvate; $8=$ chloride; $9=$ nitrite; $10=$ butyrate; $11=$ chlorate; $12=$ bromide; $13=$ nitrate; $14=$ valeric; $15=\operatorname{tartaric} ; 16=$ maleic; $17=$ sulfate; $18=$ oxalate; $19=$ phosphate; $20=$ phthalate; $21=$ citrate.

methanesulfonic acid, maleic acid were obtained. A detection limit of $2 \mu \mathrm{g} . .^{-1}$ for fluoride, chloride, nitrate, bromide, sulfate and $10 \mu \mathrm{g} . \mathrm{l}^{-1}$ for chlorate, nitrite, phosphate, estimated as suggested by IUPAC (1987), were also achieved.

\section{CONCLUSIONS}

On line sample pre-concentration coupled with auto suppression ion chromatography can be employed to increase the selectivity and sensitivity for the analyses at low concentration levels of anions without sample pretreatment. This association is an excellent tool for the quantitative determination of low molecular carboxylic acids (acetic acid, propionic acid, formic acid, butyric acid, glycolic acid, pyruvate, tartaric acid, phthalic acid, methanesulfonic acid, valeric acid, maleic acid, oxalic acid, chlorate, citric acid) and inorganic anions (fluoride, chloride, nitrite, nitrate, bromide, sulfate and phosphate) in river water and analysis time of 24 minutes. The AS15 selectivity and high capacity allow the determination of low levels of inorganic anions and low molecular weight organic acids using large volume loop injection. Furthermore, the method offers the advantages of good linearity, high precision, accuracy and easy operation. This method does not require any complicated sample preparation, allowing its use on a routinely basis.

\section{ACKNOWLEDGEMENTS}

The authors are grateful to FAPESP (Fundação de Amparo a Pesquisa do Estado de São Paulo), CNPq (Conselho Nacional de Desenvolvimento Científico e Tecnológico), LBA (The Large Scale Biosphere Atmosphere Experiment in Amazonia) to grant and financial support.

\section{LITERATURE CITED}

Albert, D.; Martens, C.S., 1997. Determination of low-molecularweight organic acid concentrations in seawater and pore-water samples via HPLC. Marine Chemistry, 56: 27.

Chen, Z.; Tang, C.; Xu, J., 1999. Non-suppressed conductivity and indirect UV detection of carboxylic acids in environmental samples by ion-exclusion chromatography using 2,6-pyridinedicarboxylic acidic eluent, Journal of Chromatography A, 859: 173.

Dahlén, J.; Hagberg, J.; Karlsson, S., 2000. Analysis of low molecular weight organic acids in water with capillary zone electrophoresis employing indirect photometric detection, Fresenius J. Anal. Chem., 366: 488.

Ding, M.Y.; Chen, P.R.; Luo, G.A., 1997. Simultaneous determination of organic acids and inorganic anions in tea by ion chromatography, Journal of Chromatography A, 764: 341.

Eiteman, M.A.; Chastain, M.J., 1997. Optimization of the ionexchange analysis of organic acids from fermentation, Analytica Chimica Acta, 338: 69.

Fang, Z.; 1993. Flow Injection Separation and Preconcentration, New York. 300pp.

Findlay, S.E.G; Sinsabaugh, R.L., 2003. Aquatic Ecosystems. Interactivity of Dissolved Organic Matter. 512pp.

IUPAC Analytical Methods Committee, 1987. Analyst 112: 199pp.

Karlsson, S.; Wolrath, H.; Dahlén, J., 1999. Influence of filtration, preservation and storing on the analysis of low molecular weight organic acids in natural waters. Water Res, 33(11): 2569.

Klampf, C.W.; Buchberger, W.; Haddad, P.R., 2000. Determination of organic acids in food samples by capillary zone electrophoresis, Journal of Chromatography A, 881: 357.

Kuiters, A.T.; Denneman, C.A.J., 1987. Water-soluble phenolic substances in soils under several coniferous and deciduous tree species, Soil Biol. Biochem., 19: 765. 
Morales, M.L.; Gonzalez, A.G.; Troncoso, A.M., 1998. Ion-exclusion chromatographic determination of organic acids in vinegars, Journal of Chromatography A, 822: 45.

Obernostere, I.; Kraay, G.; Ranitz, E.; Hernadl, G.J., 1999. Concentratios of low molecular weight carboxylic acids and carbonyl compounds in the Aegean Sea (Eastern Mediterranean) and the turnover of pyruvate. Aquatic Microbial Ecology, 20: 147.

Sharma, A.K.; Clauss, S.A.; Mong, G.M.W; Campbell, J.A., 1998. Analysis and quantification of organic acids in simulated Hanford tank waste and Hanford tank waste, Journal of Chromatography A, 805: 101.

Souza, S.R.; Tavares, M.F.M.; Carvalho, L.R.F., 1998. Systematic approach to the separation of mono- and hydroxycarboxylic acids in environmental samples by íon chromatography and capillary electrophoresis, Journal of Chromatography A, 796: 335.

Souza, S.R.; Vasconcellos, P.C.; Carvalho, L.R.F., 1999. Low molecular weight carboxylic acids in an urban atmosphere: Winter measurements in São Paulo city, Brazil, Atmospheric Environment, 33: 2563.
Strobel, B.W., 2001. Influence of vegetation on low-molecularweight carboxylic acids in soil solution - a review. Geoderma, 99:169.

Thurman, E.M.,1985. Organic geochemistry of natural waters. Dordrecht, Boston, Lancaster, 497pp.

Toofan, M.; Stilian, J.R.; Pohl, C.A.; Jackson, P.E., 1997. Preconcentration determination of inorganic anions and organic acids in power plant waters. Separation optimization through control of column capacity and selectivity, Journal of Chromatography A, 761: 163.

Vallino, J.J.; Hopkinson, C.S.; Hobbie, J.E., 1996. Modeling bacterial utilization of dissolved organic matter: Optimization replaces Monod growth kinetics. Limnology and Oceanography, 41(8): 1591.

Recebido em 10/04/2007

Aceito em 06/03/2009 